\title{
Mineral Resources of the
}

Fiddler Butte (East) Wilderness Study Area, Garfield County, Utah
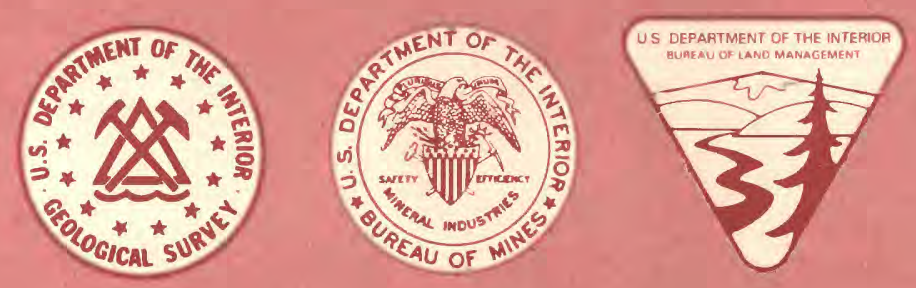

\section{U.S. GEOLOGICAL SURVEY BULLETIN 1759-B}

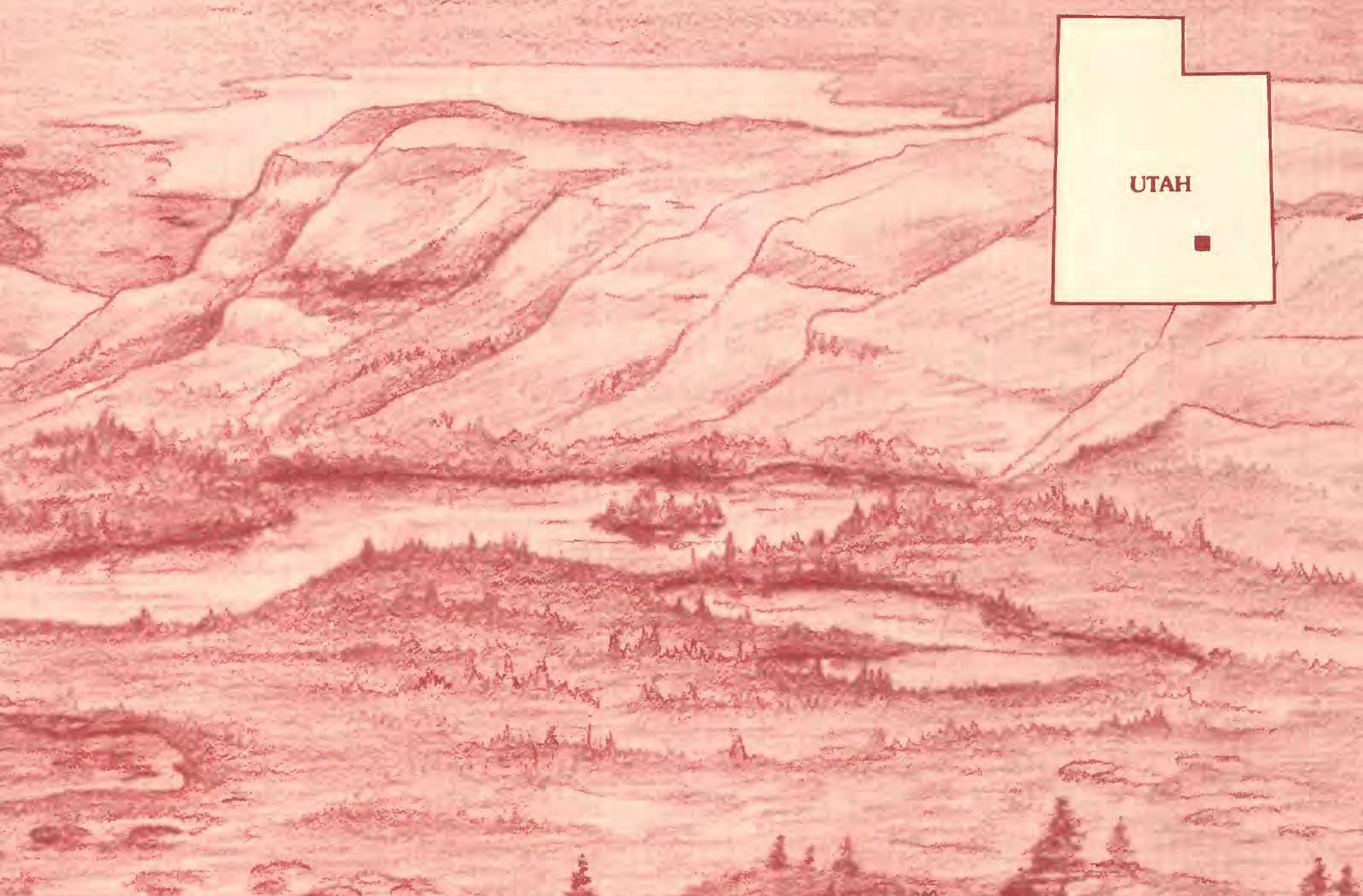



Chapter B
Mineral Resources of the
Fiddler Butte (East) Wilderness Study Area, Garfield County, Utah

By RUSSELL F. DUBIEL, GREGORY K. LEE, and PAUL P. ORKILD

U.S. Geological Survey

DIANN D. GESE

U.S. Bureau of Mines

U.S. GEOLOGICAL SURVEY BULLETIN 1759

MINERAL RESOURCES OF WILDERNESS STUDY AREAS-MISCELLANEOUS STATES 
DEPARTMENT OF THE INTERIOR

MANUEL LUJAN, JR., Secretary

\section{U.S. GEOLOGICAL SURVEY}

Dallas L. Peck, Director

Any use of trade, product, or firm names in this publication is for descriptive

purposes only and does not imply endorsement by the U.S. Government.

UNITED STATES GOVERNMENT PRINTING OFFICE: 1989

For sale by the

Books and Open-File Reports Section

U.S. Geological Survey

Federal Center

Box 25425

Denver, CO 80225

\section{Library of Congress Cataloging-in-Publication Data}

Mineral resources of the Fiddler Butte (East) Wilderness Study Area, Garfield County, Utah / by Russell F. Dubiel ... [et al.].

p. $\quad \mathrm{cm} .-$ (Mineral resources of wilderness study areas-miscellaneous

states ; ch. B) (U.S. Geological Survey bulletin ; 1759-B) (Studies

related to wilderness)

Bibliography: $p$.

Supt. of Docs. no.: I 19.3:1759-B

1. Mines and mineral resources-Utah-Fiddler Butte (East) Wilderness.

2. Fiddler Butte (East) Wilderness (Utah) I. Dubiel, Russell F.

II. Series. III. Series: U.S. Geological Survey bulletin ; 1759-B. IV. Series:

Studies related to wilderness.

QE75.B9 no. 1759-B

[TN24.U8]

$557.3 \mathrm{~s}-\mathrm{dc} 20$

[553'.09792'52]

$89-600101$ 


\section{STUDIES RELATED TO WILDERNESS}

\section{Bureau of Land Management Wilderness Study Areas}

The Federal Land Policy and Management Act (Public Law 94-579, October 21, 1976) requires the U.S. Geological Survey and the U.S. Bureau of Mines to conduct mineral surveys on certain areas to determine the mineral values, if any, that may be present. Results must be made available to the public and be submitted to the President and the Congress. This report presents the results of a mineral survey of the Fiddler Butte (East) (UT-050-241) Wilderness Study Area, Garfield County, Utah. 



\section{CONTENTS}

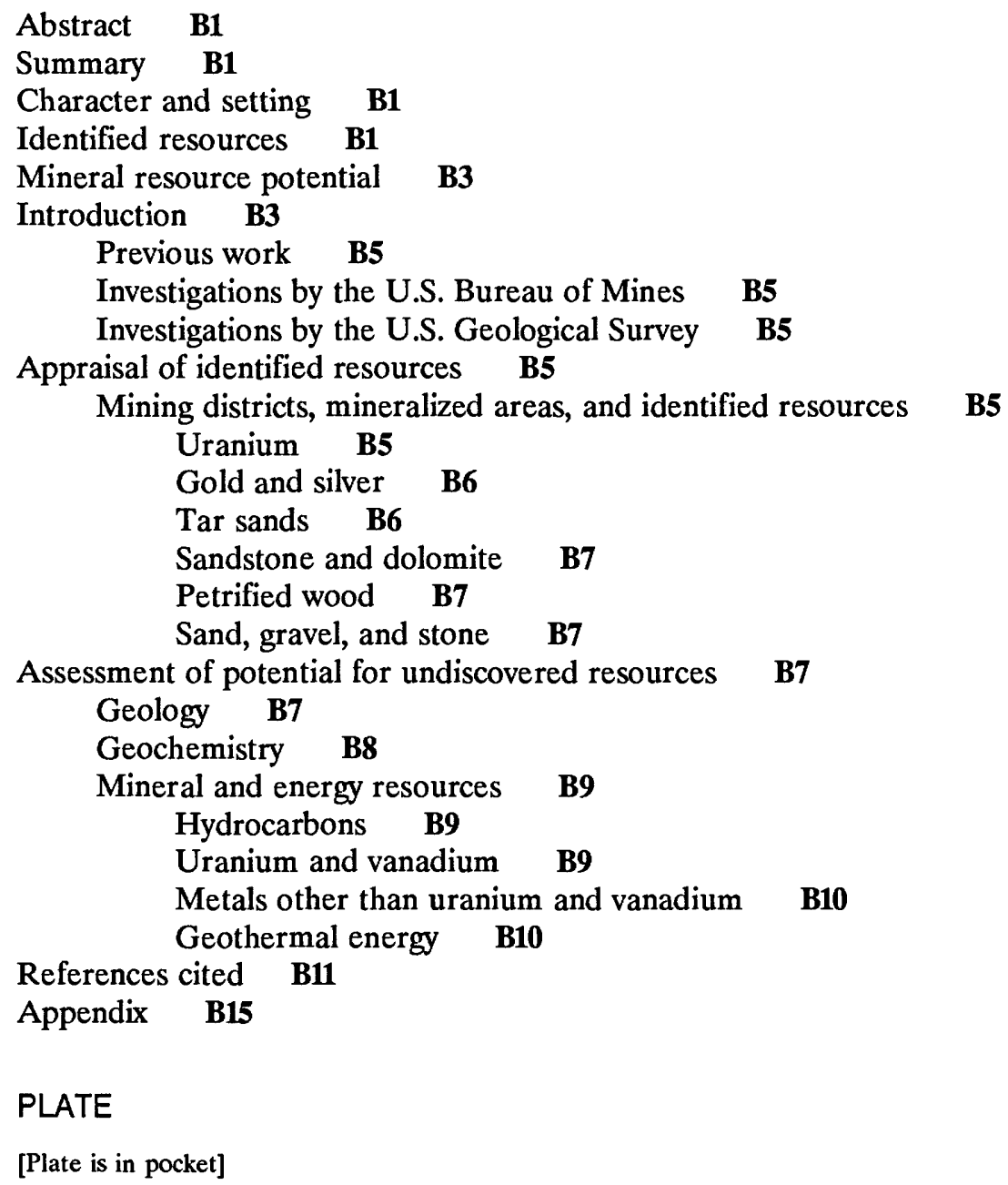

\section{PLATE}

[Plate is in pocket]

1. Map showing mineral resource potential and geology of the Fiddler Butte (East) Wilderness Study Area, Garfield County, Utah.

\section{FIGURES}

1-3. Maps showing:

1. Summary of mineral resource potential of the Fiddler Butte (East) Wilderness Study Area $\quad$ B2

2. Location of the Fiddler Butte (East) Wilderness Study Area and vicinity B4

3. Distribution of the fluvial systems of the Shinarump and Monitor Butte Members of the Chinle Formation, authigenic dolomite, and black carbonaceous mudstones used to evaluate uranium potential in the Fiddler Butte (East) Wilderness Study Area and vicinity 



\title{
Mineral Resources of the Fiddler Butte (East) Wilderness Study Area, Garfield County, Utah
}

\author{
By Russell F. Dubiel, Gregory K. Lee, and \\ Paul P. Orkild \\ U.S. Geological Survey \\ Diann D. Gese \\ U.S. Bureau of Mines
}

\section{ABSTRACT}

The Fiddler Butte (East) Wilderness Study Area has inferred subeconomic resources of tar sands (oilimpregnated sandstones) in the northeastern part of the study area (fig. 1) with in-place resources estimated to be $375-480$ million barrels of oil. High-magnesium dolomite is present within the Navajo Sandstone within the study area. The dolomite would be suitable for various industrial uses, but the remote location of the deposit makes development unlikely. Common sand, gravel, and stone in the study area have no unique qualities and are not likely to be developed. Abundant petrified wood, suitable for collecting and polishing, is present in mudstones of the Chinle Formation within the study area. The southwestern part of the study area has a moderate mineral resource potential for undiscovered tar sands as localized deposits within the White Rim Sandstone. The entire study area has a moderate resource potential for undiscovered uranium and vanadium, for oil and gas, for small isolated occurrences of precious (silver and gold) metals, and a low potential for geothermal resources and other undiscovered metals.

\section{SUMMARY}

\section{Character and Setting}

The Fiddler Butte (East) (UT-050-241) Wilderness Study Area is the easternmost of two parcels designated as the Fiddler Butte Wilderness Study Area. The geology and

Manuscript approved for publication, May 1, 1989 mineral resource potential of the Fiddler Butte (UT-050-241) Wilderness Study Area, the westernmost of the two parcels, was reported in Larson, Bromfield, and others (1985) and in Larson, Dubiel, and others (1985). The present report discusses the mineral resource potential of the Fiddler Butte (East) Wilderness Study Area.

The Fiddler Butte (East) Wilderness Study Area comprises 5,700 acres east of the Henry Mountains, Garfield County, Utah, and lies between the Dirty Devil River and the Colorado River. Field and laboratory investigations were conducted by the USGS (U.S. Geological Survey) from 1981 to 1988 and by the USBM (U.S. Bureau of Mines) in 1987. The area was studied for identified (known) resources as well as for mineral resource potential (undiscovered resources).

The Fiddler Butte (East) Wilderness Study Area is on the gently westward-dipping, northwest flank of the Monument upwarp, which merges to the west into the Henry basin. Numerous joints and normal faults of minor displacement trend northwest across the study area. Sedimentary rocks ranging in age from Pennsylvanian to Early Jurassic (see geologic time chart in the Appendix) were eroded to form a highly dissected topography that has wide and deep canyons and isolated mesas. There are no perennial streams in the study area; the Colorado River lies several miles east of the study area within a deep gorge and is the only perennial water in the area. Vegetation is sparse and precipitation is low.

\section{Identified Resources}

There are inferred subeconomic resources of tar sands (oil-impregnated sandstones) primarily within the Permian White Rim Sandstone in the northeastern part of the study 


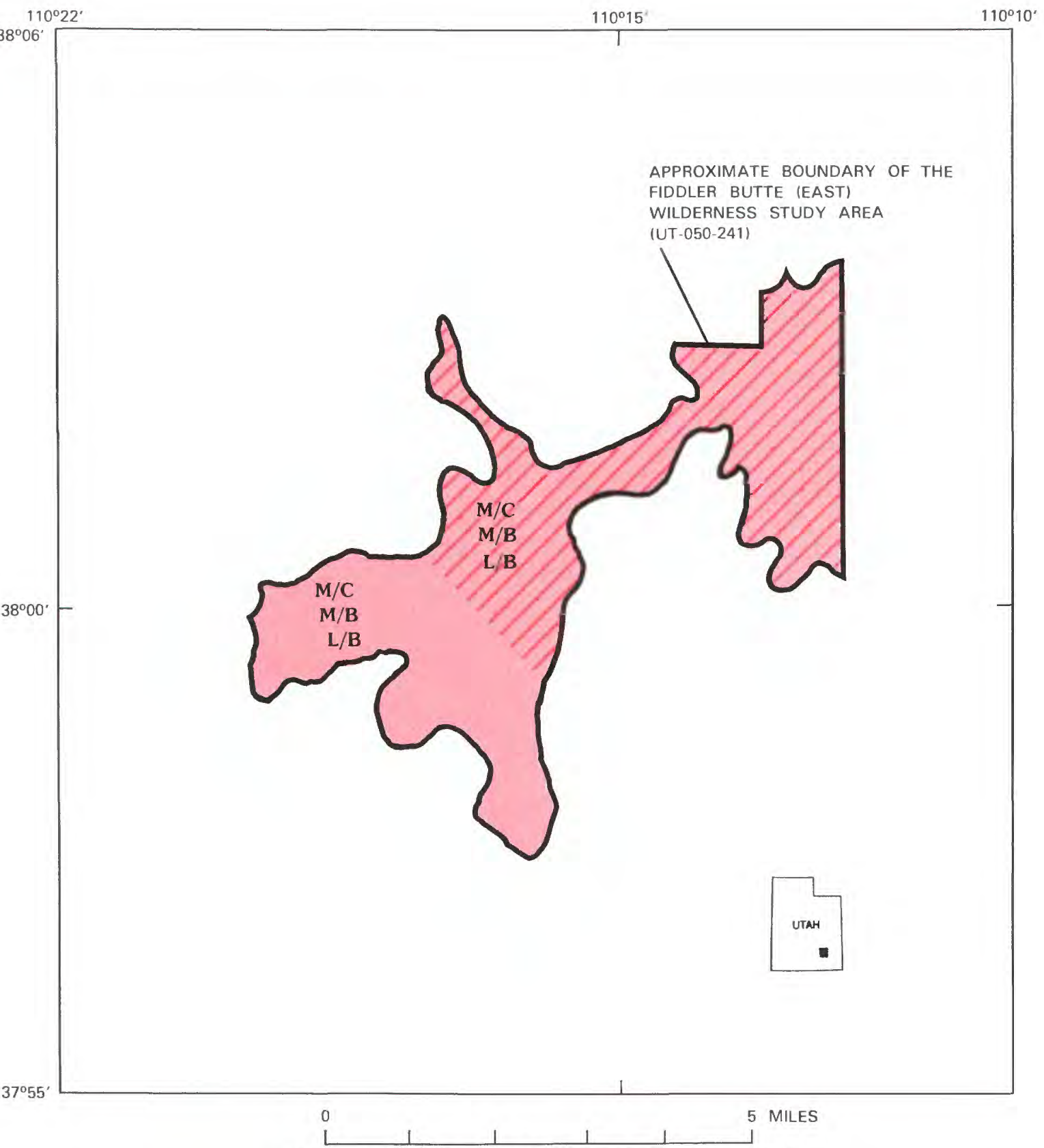

EXPLANATION OF MINERAL RESOURCE POTENTIAL

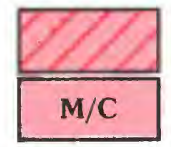

Geologic terrane having identified tar sand resources-Applies to the northeastern part of study area

Geologic terrane having moderate mineral resource potential for tar sand (applies to southwestern part of study area) and uranium and vanadium (applies to entire study area), with certainty level C

\section{M/B}

Geologic terrane having moderate mineral resource potential for oil and gas and precious (gold and silver) metals, with certainty level B-Applies to entire study area

\section{L/B}

Geologic terrane having low resource potential for geothermal energy and all metals other than those noted above, with certainty level B-Applies to entire study area

Levels of certainty

B Available information suggests level of resource

C Available information gives good indication of level of mineral potential

Figure 1. Summary map showing mineral resource potential of the Fiddler Butte (East) Wilderness Study Area, Garfield County, Utah. 
area. The study area lies partly within the Tar Sand Triangle, an area in southeastern Utah containing a single large deposit of tar sands. The Tar Sand Triangle contains an estimated 12.5-16 billion barrels of oil. Assuming uniform oil distribution throughout the deposit, 375-480 million barrels of oil are estimated to exist within the White Rim Sandstone in the study area. High-magnesium dolomite exists in the form of a 20 -ft-thick bed within the Navajo Sandstone in the study area. The deposit is unlikely to be developed due to its remote location. Sand, gravel, and stone in the study area are unlikely to be developed due to the lack of unique qualities and the remote location. The Chinle Formation within the study area contains abundant petrified wood suitable for collecting and polishing.

\section{Mineral Resource Potential}

Tar sands are defined in this report as any consolidated rock that contains a crude oil too viscous at natural reservoir temperature to be retrievable by conventional primary recovery techniques. In southeastern Utah, the Tar Sand Triangle is considered to be a single large deposit of tar sands. The Tar Sand Triangle lies north of the Colorado River, and between the Green River on the east and the Dirty Devil River on the west, underlying an area of more than 200 mi2 (square miles) that includes the Fiddler Butte (East) Wilderness Study Area. The hydrocarbons are trapped in the updip stratigraphic pinchout of the Permian White Rim Sandstone on the northwest flank of the Monument upwarp and, to a much lesser extent, in the Permian Cedar Mesa Sandstone and the Triassic Moenkopi Formation (Campbell and Ritzma, 1982). Investigations of the regional geology indicate that the White Rim Sandstone underlies the study area, but that the thickness of the White Rim Sandstone and the content of tar sands within the White Rim decrease in the southwestern part of the study area. The northeastern part of the study area contains inferred subeconomic resources of tar sands (see "Identified Resources," this report), and the southwestern part of the study area is considered to have a moderate mineral resource potential for localized deposits of tar sands in the White Rim Sandstone.

Known uranium and vanadium occurrences in the region are restricted to fluvial sandstones of the Shinarump and Monitor Butte Members of the Upper Triassic Chinle Formation. The Chinle Formation is known to contain uranium and vanadium in the White Canyon area about $20 \mathrm{mi}$ south of the study area, in the vicinity of Capitol Reef National Park about 45 mi northwest of the study area, and in Poison Spring Canyon, North Hatch Canyon, and South Hatch Canyon surrounding the study area in the vicinity of Fiddler Butte. Recent drilling has identified a subeconomic resource of uranium in the Chinle Formation about $25 \mathrm{mi}$ southwest of the study area near Mt. Ellsworth in the Henry Mountains. The uranium and vanadium deposits of the Chinle Formation in each of these areas are restricted to fluvial sandstones of the Shinarump and Monitor Butte Members. Sedimentologic study of these fluvial systems indicates that they crop out within and underlie the Fiddler Butte (East) Wilderness Study Area. Organic-carbon-rich, black mudstones and authigenic dolomite in the Chinle associated with uranium mineralization occur in canyons immediately adjacent to the study area. The occurrence of fluvial sandstones of the Chinle Formation within the study area, the proximity of organic mudstones and authigenic dolomite associated with uranium mineralization, and the occurrence of known, but small, uranium deposits indicated by extensive prospecting in the area indicate that the study area has a moderate mineral resource potential for uranium and vanadium.

Oil and gas have been produced from Pennsylvanian, Permian, and Triassic rocks in basins adjacent to the Henry basin and Monument upwarp, but although these same strata are known to occur in the subsurface of the study area, they remain mostly untested. Investigations of the regional geology and occurrence of possible hydrocarbon-bearing units within the study area are coupled with limited knowledge on the exact subsurface distribution of these rocks and their hydrocarbon content. Present information indicates that the entire study area has a moderate mineral resource potential for oil and gas.

Stream-sediment and rock samples were collected by the USGS from the Fiddler Butte (East) Wilderness Study Area and vicinity for geochemical analysis. Analyses of rock, stream-sediment, and heavy-mineral panned-concentrate samples suggest that the study area is generally lacking in mineral enrichment. However, two heavy-mineral pannedconcentrate samples collected by the USGS outside the study area boundary contain anomalous amounts of silver and gold; one heavy-mineral panned-concentrate sample collected by the USBM contains gold above the detection limit of $0.001 \mathrm{oz} / \mathrm{st}$ (ounces per short ton), and one rock-chip sample from the Chinle Formation collected by the USBM contains a minor amount of silver. These anomalies probably represent isolated occurrences related to the presence of minor amounts of precious (silver and gold) metals in rocks of the Chinle Formation within the study area. The study'area is considered to have a moderate mineral resource potential for small isolated occurrences of precious (silver and gold) metals and low resource potential for other metals, except as noted earlier.

There is no evidence, such as heated waters or associated mineral deposits, to suggest any shallow occurrence of geothermal sources, and the study area is considered to have a low potential for geothermal resources.

\section{INTRODUCTION}

The Fiddler Butte (East) (UT-050-241) Wilderness Study Area is the easternmost of two parcels designated as the Fiddler Butte Wilderness Study Area. The geology and mineral resource potential of the Fiddler Butte (UT-050-241) Wilderness Study Area, the westernmost of the two parcels, was reported in Larson, Bromfield, and others (1985) and in Larson, Dubiel, and others (1985). The present report discusses the mineral resource potential of the Fiddler Butte (East) Wilderness Study Area.

The Fiddler Butte (East) Wilderness Study Area comprises about 5,700 acres east of the Henry 
Mountains in Garfield County, Utah, and is located about $15 \mathrm{mi}$ north of Hite and about $35 \mathrm{mi}$ southeast of Hanksville (fig. 2). The study area is partly within and is bounded on the south, east, and west by Glen Canyon National Recreation Area (pl. 1). Access to the study area may be gained by an unimproved dirt road in Poison Spring Canyon east from Utah State Highway 95 along North Wash and by an unimproved dirt road north from Utah State Highway 95 where it crosses the Colorado River.

The Fiddler Butte (East) Wilderness Study Area is within the Canyonlands section of the Colorado Plateau, an area of steep, incised canyons, rolling hills, and benchlands. The study area encompasses a large flattopped mesa known collectively as The Block, encompassing the North Block and South Block, with a prominent butte at the southernmost point known as the Sewing Machine (pl. 1). The mesa is ringed by vertical to near-vertical cliffs several hundred feet high. A primitive hiking trail provides access within the study area. Elevations within the study area range from about 5,600 $\mathrm{ft}$ along the western boundary to about 7,100 ft on North Block. Vegetation is sparse and precipitation is low.

This report presents an evaluation of the mineral endowment (identified resources and mineral resource potential) of the study area and is the product of separate studies by the U.S. Bureau of Mines (USBM) and the U.S. Geological Survey (USGS). Identified resources are classified according to the system of the U.S. Bureau of Mines and the U.S. Geological Survey (1980), which is shown in the Appendix of this report. Identified resources were studied by the USBM. Mineral resource potential is the likelihood of occurrence of undiscovered concentrations of metals and nonmetals, industrial rocks and minerals, and of undiscovered energy sources (coal, uranium, oil, gas, oil shale, tar sands, and geothermal sources). Mineral resource potential and the level of certainty of the resource assessment were classified

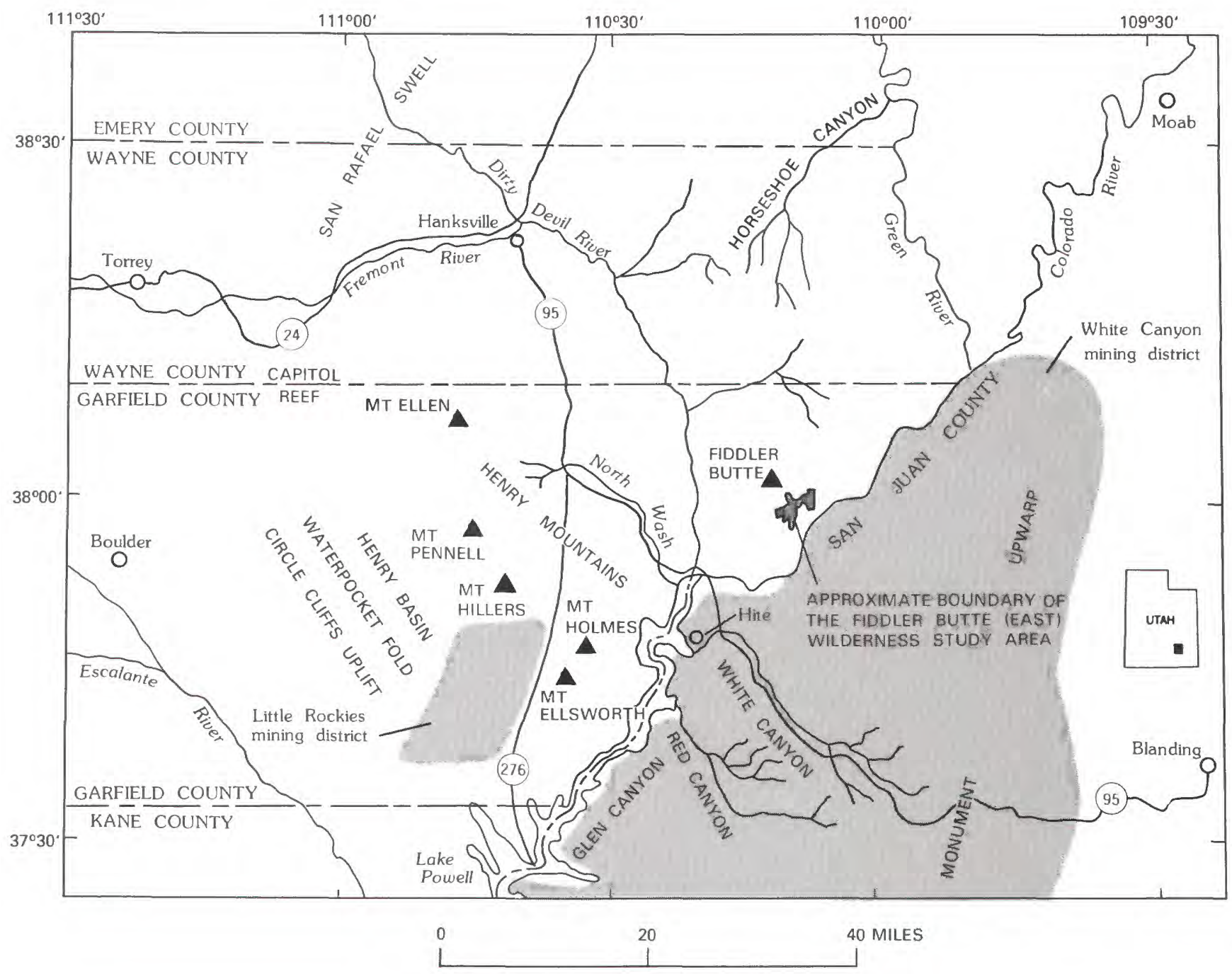

Figure 2. Index map showing location of the Fiddler Butte (East) Wilderness Study Area, Garfield County, Utah, and vicinity. 
according to the system of Goudarzi (1984; see Appendix). The potential for undiscovered resources was studied by the USGS.

\section{Previous Work}

Major J.W. Powell, during the exploration of the Green and Colorado Rivers by boat in 1869 and 1871, was probably the first geologist to examine the region surrounding the study area (Powell, 1875). McKnight (1940) made the first thorough investigation of the geology between the Green and the Colorado Rivers. Baker (1946) studied the Green River desert and the Cataract Canyon region, which include and surround the study area. To date, uranium has been the only mineral commodity of economic importance in the region. Johnson (1959) summarized the uranium resources of the area including the Henry Mountains and the area between the Dirty Devil and Colorado Rivers. Uranium deposits in the region have been described by Doelling (1967), and many investigations were conducted by, or done under contract to, the Atomic Energy Commission (now the Nuclear Regulatory Commission) in the 1940's and 1950's. These reports are available through the Grand Junction, Colo., office of the Nuclear Regulatory Commission. More recently, recognition of tar sand deposits in southeastern Utah has resulted in several publications that review and characterize the nature of hydrocarbon occurrences in the White Rim Sandstone (see for example, Ritzma, 1974, 1979; Campbell, 1975; Campbell and Ritzma, 1979, 1982; Ball and others, 1982; and references therein). A recent field trip guidebook summarizes several aspects of the geology of the region that includes the study area (Campbell, 1987). Briggs (1982), Larson, Bromfield, and others (1985), and Larson, Dubiel, and others (1985) reported on the geology, identified resources, and mineral resource potential of the Fiddler Butte Wilderness Study Area encompassing about 27,000 acres just west of the Fiddler Butte (East) Wilderness Study Area.

\section{Investigations by the \\ U.S. Bureau of Mines}

In 1987, the USBM evaluated the identified resources of the Fiddler Butte (East) Wilderness Study Area. Mineral, geothermal, and oil and gas lease information was gathered from published and unpublished literature, interviews with people knowledgeable about the area, USBM files, and oil and gas and mining-claim records from Garfield County, Utah, and from the U.S. Bureau of Land Management (BLM) office in Salt Lake City, Utah (Gese, 1988). Field studies during April 1987 included a search for mines, prospects, and mineralized areas within and in the vicinity of the study area. The USBM collected 19 rock-chip samples and 1 panned-concentrate sample from friable material taken at an outcrop, determined assay values, and reviewed past exploration activity in the study area.

Sixteen samples were analysed for gold and silver by fire assay and for 32 other elements by inductively coupled plasma-atomic emission spectroscopy. Two samples were analysed for platinum by atomic absorption spectroscopy. Four rock-chip samples were analysed to determine their suitability for industrial use by inductively coupled plasma-atomic emission spectroscopy. All analyses were performed by Chemex Labs, Inc., Sparks, Nev. A complete data set for these samples may be found in Gese (1988) and is also available for public inspection at the USBM, Intermountain Field Operations Center, Building 20, Denver Federal Center, Denver, Colo.

\section{Investigations by the U.S. Geological Survey}

From 1981 to 1988, the USGS assessed the potential for undiscovered mineral resources of the Fiddler Butte (East) Wilderness Study Area. The studies consisted of geologic mapping (Larson, Bromfield, and others, 1985; Paul P. Orkild, unpub. data); a search for mines, prospects, and mineralized areas; sedimentologic studies (Dubiel, 1982, 1983a,b); and rock and streamsediment sampling for geochemical analysis. Models developed for the occurrence of uranium (Dubiel, 1983b) were applied to the evaluation of mineral resource potential in the study area.

\section{APPRAISAL OF IDENTIFIED RESOURCES}

\section{By Diann D. Gese \\ U.S. Bureau of Mines}

\section{Mining Districts, Mineralized Areas, and Identified Resources}

\section{Uranium}

The Fiddler Butte (East) Wilderness Study Area is in the Orange Cliffs area of the Henry Mountains mining district. Intermittent exploration for uranium in the region has taken place since the 1950's. Several small 
uranium mines and prospects are outside the study area, but only the Buckacre Point mine and the Cedar Point mine, both about $5 \mathrm{mi}$ northwest of the study area, have any recorded production. Total production for both mines is about 7,500 tons of uranium ore of unknown grade (Briggs, 1982). Contiguous uranium mining claims partly encircle the perimeter of the study area.

Sites of reported uranium occurrences within and near the study area were checked with a scintillometer and sampled where scintillometer readings were highest. Six rock-chip samples were collected from the lower unit of the Chinle; three contained 9-290 ppm (parts per million) uranium, and one sample contained $2.2 \mathrm{ppm}$ silver. Although uranium has been mined from the Monitor Butte Member of the Chinle Formation northwest of the study area at Buckacre and Cedar Points, sample results do not indicate economically significant uranium concentrations at the surface.

\section{Gold and Silver}

The Cove Gold claim group, in sec. 14, T. 32 S., R. $15 \mathrm{E}$., in Cove Canyon on the south boundary of the study area (pl. 1) is the site of recent exploration activity for precious (gold and silver) metals in the Chinle Formation. The claim block has been leased and the lessees have collected samples from the base of the Chinle Formation that reportedly contain as much as 2.5 oz gold/st and $15.3 \mathrm{oz}$ silver/st (DeForrest Smouse, geological consultant, Centerville, Utah, unpub. data, 1984).

Gold in the Chinle Formation was reported by Lawson (1913) and silver has been mined from a sandstone in the Chinle Formation in the Silver Reef (Harrisburg) mining district about $150 \mathrm{mi}$ southwest of the study area in Washington County, Utah (Proctor, 1953). Nine rock-chip samples and one pannedconcentrate sample were collected from a 10-ft-thick, gray to dark-green, friable sandstone in the Chinle Formation in Cove Canyon. Only the pannedconcentrate sample (Gese, 1988, sample 6, table 1) contained gold $(0.012 \mathrm{oz} / \mathrm{st})$ above the detection limit $(0.001 \mathrm{oz} / \mathrm{st})$. A minor amount of silver $(2.2 \mathrm{ppm}$ (parts per million)) was detected in one sample (Gese, 1988, sample 15, table 1) collected from a sandstone unit in the Chinle. Although gold and silver were detected in these samples, the concentrations are too low and isolated to constitute assignment as a resource.

\section{Tar Sands}

The Fiddler Butte (East) Wilderness Study Area is partly within the Tar Sand Triangle oil-impregnated sandstone deposit, the largest tar sand deposit in Utah. The deposit underlies an area greater than $200 \mathrm{mi}^{2}$
(Doelling, 1975), and hydrocarbons are trapped by the stratigraphic pinchout of the Permian White Rim Sandstone on the northwest plunge of the Monument upwarp. The White Rim Sandstone contains about 99 percent of the oil in the deposit; the rest of the deposit is in the overlying Moenkopi Formation and the underlying Organ Rock Formation and the Cedar Mesa Sandstone (Doelling, 1975). The presence of oil-impregnated rock in the area has been known since at least 1912 when assessment wells were drilled in Elaterite basin (Doelling, 1975). Twelve petroliferous rock samples from the Permian White Rim Sandstone were analyzed by Wood and Ritzma (1972). Tar content of the samples ranged from 2.0 to 91.8 percent; carbon content ranged from 73.8 to 85.2 percent; hydrogen content ranged from 5.8 to 11.8 percent; nitrogen content ranged from 0.3 to 0.7 percent; sulfur content ranged from 2.67 to 6.27 percent; and specific gravity ranged from 1.003 to $1.080 \mathrm{~g} / \mathrm{cm}^{3}$ (grams per cubic centimeter) (Wood and Ritzma, 1972).

The Tar Sand Triangle was designated a Special Tar Sand Area (STSA) in 1980 by the USGS. In December, 1982, a group of lessees applied to the BLM to convert their Federal oil and gas leases in the STSA to combined hydrocarbon leases, as provided by the Combined Hydrocarbon Leasing Act of 1981. The application proposed to unitize the leases into a single 66,040-acre operating unit and to commercially develop the tar sands. A draft environmental impact statement (DEIS) was issued in July 1984 to provide the Regional Director, National Park Service (NPS) and the State Director, BLM, with the information to determine whether combined hydrocarbon leases should be issued. The NPS and the BLM did not reach an agreement as to what alternative action proposed in the DEIS should be followed, and the decision was passed to the Secretary of the Interior. To date, no decision has been made and no combined hydrocarbon leases have been issued (Carol McCoy, Policy Regulation Section Chief, Mining and Minerals Branch, NPS, oral commun., June 1988).

About 70 percent $(4,000$ acres) of the study area comprising the northeastern part overlies the Tar Sand Triangle STSA (Gese, 1988, pl. 1). Campbell and Ritzma (1979) showed $100 \mathrm{ft}$ of oil-impregnated White Rim Sandstone beneath the northeastern part of the study area. Ritzma (1974) estimated that 12.5-16 billion barrels of oil occur in place within the Tar Sand Triangle. Assuming a uniform distribution of oil throughout the deposit, 375-480 million barrels of oil (3 percent of the total oil resource) would exist beneath the northeastern part of the study area. Studies have shown that about 30 percent of the deposit is amenable to in-situ recovery methods (Campbell and Ritzma, 1979), whereas mining and processing may result in recovery of more than 90 percent of the deposit (Ritzma, 1974). 


\section{Sandstone and Dolomite}

Four rock-chip samples were collected from the Wingate Sandstone, Kayenta Formation, and Navajo Sandstone, to determine their suitability for industrial use (Gese, 1988, table 2). Three are sandstone samples; one is a dolomite sample from a 20 -ft-thick bed in the Navajo Sandstone. According to standards of the American Society for Testing and Materials, the silica content of the sandstones is too low and the aluminumoxide and iron-oxide content are too high for industrial uses (Coope and Harben, 1977; Davis and Tepordei, 1985). The dolomite is a high-magnesium dolomite ( $>43$ percent $\mathrm{MgCO}_{3}$ ) (Gese, 1988, sample 16, table 2) and could be used in agriculture, construction, manufacturing, and smelting (Bates, 1969; Doelling, 1975; Carr and Rooney, 1983). Both the sandstone and the dolomite are high-tonnage, low-value commodities whose value is highly dependent on the distance to market. The extreme remoteness of the study area and the commodities makes development unlikely.

\section{Petrified Wood}

Abundant petrified wood suitable for collecting and polishing is present in the Chinle Formation throughout the study area. Petrified logs as much as $10 \mathrm{ft}$ long and as much as $15 \mathrm{in}$. in diameter are common near the southern boundary of the study area.

\section{Sand, Gravel, and Stone}

Materials that could be used for construction purposes are present in the Fiddler Butte (East) Wilderness Study Area. Common-variety sand and gravel are present in terrace deposits, and several of the Mesozoic rock units could be sources of building stone. Development of these resources is unlikely due to the lack of unique qualities and the abundance of sand, gravel, and stone closer to possible markets.

\section{ASSESSMENT OF POTENTIAL FOR UNDISCOVERED RESOURCES}

\section{By Russell F. Dubiel, Gregory K. Lee, and Paul P. Orkild \\ U.S. Geological Survey}

\section{Geology}

The Fiddler Butte (East) Wilderness Study Area is located in the central part of the Colorado Plateau. Several monoclines within the region trend principally to the northwest (Baker, 1935). The study area is on the gently dipping northwest flank of the Monument upwarp and is bordered on the west by the asymmetrical Henry basin. Numerous normal faults of minor displacement transect the study area in a northwesterly direction.

Rocks exposed in the Fiddler Butte (East) Wilderness Study Area and vicinity are sedimentary, range in age from Pennsylvanian to Jurassic, and have a combined thickness of nearly 6,500 ft (pl. 1). The sedimentary rocks were deposited in both marine and continental environments (pl.1; see also Huntoon and others, 1982; Baars, 1987).

In part of the late Paleozoic Era, the Cordilleran geosyncline was located west of the Colorado Plateau and the geosyncline was the site of predominantly carbonate deposition. During the Pennsylvanian Period, marine carbonate and clastic rocks of the Honaker Trail Formation were deposited in the region of the study area. These rocks intertongue to the east with arkosic red beds. A thick wedge of clastic marine and marginal marine sediments of the Permian Cutler Group was derived predominantly from the Uncompahgre uplift to the east. Farther to the east, in the vicinity of the Uncompaghre uplift, the Cutler is composed of arkosic sandstones and conglomerates shed westward off the Ancestral Uncompaghre highlands as debris flows and fluvial deposits. To the west, and in the vicinity of the study area, the Cutler encompasses several complexly intertongued units. The Halgaito Formation (Blakey, 1979) consists of reddish-brown and purple arkosic siltstone, sandstone, and conglomerate deposited in continental to nearshoremarine environments that interfinger with thin, gray limestone deposited in marine settings. The Cedar Mesa Sandstone overlies the Halgaito and was deposited in an eolian environment in a marginal marine setting. The Cedar Mesa Sandstone interfingers with the Organ Rock Formation (Blakey, 1979). The Organ Rock was deposited in a marginal marine to continental lowland environment. In the study area, the Organ Rock is a useful marker separating the underlying Cedar Mesa Sandstone from the overlying White Rim Sandstone.

The White Rim Sandstone was deposited in a shallow-water marine and near-shore eolian environment during a major marine transgression into the region (Baars and Seager, 1970; Huntoon and Chan, 1987; Steele, 1987). The White Rim thins east of the study area onto the Monument upwarp, indicating growth of this uplift during the latest Permian (Baars, 1979).

The Late Permian and Early Triassic were dominated by erosion. Baars (1962) attributed this period of erosion, which persisted into the Early Triassic, to slight epeirogenic uplift of the entire region. The 
erosional interval resulted in an unconformable contact between the White Rim Sandstone Member and the overlying Lower and Middle(?) Triassic Moenkopi Formation.

The Moenkopi Formation was deposited on a fairly stable shelf during a series of transgressive and regressive marine cycles (Stewart and others, 1972a; Molenaar, 1987). The final regressive phase of the Moenkopi Formation probably occurred in the Middle(?) Triassic and was followed by a period of erosion that produced the disconformable contact between the Moenkopi Formation and the overlying Upper Triassic Chinle Formation. The unconformity separating the Moenkopi and Chinle Formations is highly irregular and represents large, erosional valleys cut into the Moenkopi prior to Chinle deposition.

The Chinle Formation was deposited in complexly interfingered fluvial, deltaic, and lacustrine environments (Stewart and others, 1972b; Blakey and Gubitosa, 1983; Dubiel, 1983a,b, 1987a,b,c). The Chinle Formation is unconformably overlain by the Lower Jurassic Wingate Sandstone. In earliest Jurassic time, eolian sedimentation persisted, but alternated with fluvial deposition on that part of the Colorado Plateau encompassed by the study area. The Wingate Sandstone was deposited in eolian environments. Poole and Williams (1972) and Stokes (1980) showed that winds from the north and northwest deposited the eolian sands of the Wingate Sandstone.

The Wingate Sandstone is conformably overlain by the Lower Jurassic Kayenta Formation. The Kayenta Formation was deposited in a braided fluvial environment. The Kayenta Formation is conformably overlain by the Lower Jurassic Navajo Sandstone. The Navajo Sandstone was deposited in eolian dune and interdune environments.

\section{Geochemistry}

A reconnaissance geochemical survey was conducted in and around the Fiddler Butte (East) Wilderness Study Area in 1987 to assist in the assessment of the mineral resource potential. One rock, 18 streamsediment, and 13 heavy-mineral panned-concentrate samples were collected and analysed.

Analyses of stream-sediment samples represent the chemistry of the material eroded from the drainage basin upstream from the sample site. In addition, the silt fraction of the sediment provides potential nuclei for the adsorption of dissolved metals that may be contained in the stream water. These samples are utilized to identify which drainage basins, if any, contain concentrations of elements that may be related to mineral deposits. Analyses of heavy-mineral panned-concentrate samples provide information about the chemistry of certain minerals in eroded and transported rock material derived from the contributing drainage basins. The selective concentration of panned minerals that may be orerelated permits the determination of some elements that are not easily detected in stream-sediment samples. Analyses of altered or mineralized rock samples, where present, may provide useful geochemical information about the major- and trace-element assemblages associated with a mineralizing system.

Stream-sediment samples were collected from active stream drainages in and around the study area (pl. 1). At each sample locality, a composite of fine-grained material from several sites within the drainage was collected and later air-dried prior to sieving and chemical analysis. Panned-concentrate samples of stream sediments were collected from drainages that were large enough to deposit gravel and coarser material. The panned-concentrate samples were generally taken in the vicinity of the stream-sediment samples but were collected from coarser material representing higher energy deposition. Heavy-mineral concentrate samples were obtained by panning. The samples were submitted to the laboratory for drying and analysis. A single rock sample was collected from the southwestern part of the study area in order to examine an observed bluish coloration that might indicate possible alteration.

Six-step semiquantitative emission spectographic analyses were performed on all samples using the method of Grimes and Marranzino (1968). Spectrographic analysis included determination of 33 elements for rock and stream-sediment samples and 37 elements for heavy-mineral-concentrate samples. Atomicabsorption spectrophotometry analysis for gold was performed on each panned-concentrate sample using the method of Thompson and others (1968). Streamsediment and rock samples were analysed by inductively coupled-plasma atomic emission spectrophotometry for antimony, arsenic, bismuth, cadmium, and zinc using the method of Crock and others (1987). Rock and streamsediment samples were analysed for uranium using a modification of the fluorometric method described by Centanni and others (1956).

Statistical distributions of the analytical data (G.K. Lee, unpub. data) and comparison with average crustal abundances of the elements in comparable geologic terranes (Rose and others, 1979) indicate that the study area is generally lacking in mineral enrichment. However, two heavy-mineral panned-concentrate samples collected from drainages on the north and south side of the study area show anomalous amounts of silver and gold. Silver $(70 \mathrm{ppm})$ and gold $(0.75 \mathrm{ppm})$ were found in sample 11, and gold (0.05 ppm) was detected in sample 18 (pl. 1). These anomalies appear to be isolated occurrences and are apparently related to the presence of the Chinle Formation within the drainage basins. Gold 
has been reported to occur in small quantities in the Chinle Formation (Lawson, 1913; Butler and others, 1920), but no large accumulations have been found.

\section{Mineral and Energy Resources}

Evaluation of the mineral resource potential of the Fiddler Butte (East) Wilderness Study Area is based on: (1) geologic investigations (pl. 1; Larson, Bromfield, and others, 1985; Paul P. Orkild, unpub. data); (2) geochemical investigations; (3) development of uraniummineralization models (fig. 3; Dubiel, 1983b); and (4) previously published studies on the geology and mineral occurrences of the study area (Doelling, 1967, 1975; Molenaar and others, 1983, Molenaar and Sandberg, 1983).

\section{Hydrocarbons}

Tar sands are defined in this report as any consolidated rock that contains crude oil too viscous to flow at natural reservoir temperature to be retrievable by conventional primary recovery techniques (Ball and others, 1982). In southeastern Utah, the Tar Sand Triangle is considered to be a single large deposit of tar sands. The Tar Sand Triangle is north of the Colorado River and between the Green River on the east and the Dirty Devil River on the west; it underlies an area of more than $200 \mathrm{mi}^{2}$ that includes the northeastern part of the study area. The hydrocarbons are trapped in the updip stratigraphic pinchout of the Permian White Rim Sandstone on the northwest flank of the Monument upwarp, and, to a lesser extent, in the underlying Permian Cedar Mesa Sandstone and the overlying Triassic Moenkopi Formation (Campbell and Ritzma, 1982). About 99 percent of the oil impregnation is in the White Rim Sandstone (Ritzma, 1979). Geologic mapping in the region indicates the White Rim Sandstone underlies the entire study area (pl. 1; Paul P. Orkild, unpub. data). Studies of the distribution of tar sands in the White Rim Sandstone and the location of the Tar Sand Triangle divide the study area into two parts. The northeastern part of the study area is underlain by the tar sand-bearing part of the White Rim Sandstone and is included in the Tar Sand Triangle. The nortineastern part of the study area has identified resources of tar sands (pl. 1) and is discussed in the section of this report on "Appraisal of Identified Resources." Studies of the Tar Sand Triangle by Campbell and Ritzma (1982) indicate that the deposit feathers out to the southwest along the dividing line. Campbell and Ritzma (1982) indicated that the White Rim Sandstone southwest of this line contains isolated pods of oil-impregnated sandstone, and they apparently did not include these deposits in calculations of reserves for the Tar Sand Triangle. The southwestern part of the study area is underlain by strata of the White Rim Sandstone that may contain additional isolated pods of tar sand deposits. Based on the occurrence of the White Rim Sandstone in the subsurface of this part of the study area, the occurrence of known tar sands in the White Rim in the Tar Sand Triangle, and known isolated pods of tar sands in the White Rim surrounding this part of the study area, the southwest part of the study area is considered to have moderate mineral resource potential for undiscovered tar sand deposits in localized pods within the White Rim Sandstone. A certainty level of $C$ is assigned on the basis of known occurrences and identified resources within the northeastern part of the study area, the occurrence of similar host rocks in the southwestern part of the study area, and geologic studies that indicate isolated pods of tar sand deposits in outcrops adjacent to the southwestern part of the study area.

Oil and gas have been produced from Pennsylvanian, Permian, and Triassic rocks in basins adjacent to the Monument upwarp, and these same strata are known to occur in the subsurface of the study area; however, they remain mostly untested. The study area is on the western margin of the Paradox basin, a large depositional basin that formed during Pennsylvanian time. The Paradox basin contains strata that are favorable hosts for hydrocarbons, and rocks of similar age and depositional setting may be expected to occur in the subsurface of the study area. However, factors detrimental to oil and gas accumulation in the study area, such as the extensive dissection of the region by the Colorado River and its tributaries, especially in Cataract Canyon $7 \mathrm{mi}$ east of the study area, would have lowered reservoir pressures by exposing reservoir rocks (Irwin and others, 1980). Stratigraphic pinchouts of other strata may have been controlled by the Monument upwarp, and those units may contain hydrocarbons in a setting similar to that of the tar sands in the White Rim Sandstone. The Fiddler Butte (East) Wilderness Study Area has been assessed as having a moderate resource potential for oil and gas, on the basis of data from this study and from studies by Molenaar and others (1983) and Molenaar and Sandberg (1983). A certainty level of $B$ is assigned on the basis of the regional geology and occurrence of possible hydrocarbon-bearing units within the study area, coupled with a lack of precise knowledge on the exact subsurface distribution of these rocks and their hydrocarbon content.

\section{Uranium and Vanadium}

Uranium and vanadium occurrences in the Canyonlands country between the Colorado River and North Wash in the vicinity of the study area are restricted to fluvial sandstones of the Shinarump and Monitor Butte Members in the Upper Triassic Chinle Formation. The 
Chinle Formation is known to contain uranium and vanadium in the White Canyon area about $20 \mathrm{mi}$ south of the study area, in the vicinity of Capitol Reef National Park about $45 \mathrm{mi}$ northwest of the study area, and in Poison Spring Canyon, North Hatch Canyon, and South Hatch Canyon surrounding the study area in the vicinity of Fiddler Butte. Recent drilling has identified a subeconomic resource of uranium in the Chinle Formation about $25 \mathrm{mi}$ southwest of the study area near Mt. Ellsworth in the Henry Mountains, underscoring the opportunity for new discoveries. The uranium and vanadium deposits of the Chinle Formation in each of these areas also are restricted to fluvial sandstones of the Shinarump and Monitor Butte Members. Sedimentologic analysis of these fluvial systems based on paleochannel trends extrapolated from outcrops within and adjacent to the study area (Dubiel, 1983b, 1987a, b) indicates that the fluvial depositional systems of the Shinarump Member trend west from the area of White Canyon and north to northwest through the area of Capitol Reef National Park (fig. 3). The sedimentology studies also indicate that the fluvial depositional systems of the Monitor Butte Member trend north in the area of North Wash and Fiddler Butte, and underlie the Fiddler Butte (East) Wilderness Study Area.

Studies by Northrup (1982) of uranium deposits in the Morrison Formation of the Henry basin suggest that authigenic dolomite occurs in fluvial sandstone beds that contain uranium and vanadium deposits. Rock samples from the lower part of the Chinle Formation, including the Shinarump and Monitor Butte Members, were collected during this study for dolomite analysis where the Chinle is exposed around the Henry basin. X-ray diffraction studies indicate that the areas of greatest concentration of authigenic dolomite coincide with the areas of Shinarump and Monitor Butte paleochannel systems (fig. 3), thus supporting the concept that Shinarump and Monitor Butte fluvial systems may have some potential for uranium deposits.

Carbonaceous lacustrine mudstones, similar to those reported to be related to Morrison Formation uranium deposits (Peterson, 1977), are also abundant in the lower part of the Chinle Formation (Dubiel, 1983a,b, 1987b) and in the same areas that contain the fluvial systems and the authigenic dolomite (fig. 3). The coincidence of carbonaceous mudstones and authigenic dolomite coupled with the location of paleochannel systems that may host ore deposits underlying the study area indicate that the mineral resource potential for uranium and vanadium is moderate in the lower part of the Chinle Formation. The moderate mineral resource potential for uranium and vanadium is assigned a certainty level of $\mathrm{C}$ based on the known occurrences of uranium and vanadium deposits in the Chinle Formation in the region surrounding the study area, the occurrence of similar host rocks within the study area, and the application of a mineral-occurrence model developed for the region that projects trends favorable for the formation of uranium and vanadium deposits into the study area. Copper and other metals such as cobalt and nickel may be associated with this area of uranium and vanadium potential because these metals are known to occur in uranium deposits in the Shinarump Member in other places on the Colorado Plateau (Shoemaker and others, 1959), although the present data do not indicate their presence.

\section{Metals Other than Uranium and Vanadium}

Stream-sediment and rock samples were collected from the Fiddler Butte (East) Wilderness Study Area and vicinity for geochemical analysis to evaluate the mineral resource potential for metals other than uranium and vanadium. Analyses of rock, stream-sediment, and heavy-mineral panned-concentrate samples indicate that the study area is generally lacking in mineral enrichment. Two heavy-mineral panned-concentrate samples collected outside the study area boundary contain anomalous amounts of silver and gold, one heavymineral panned-concentrate sample collected by the USBM contains gold above the detection limit, and one rock-chip sample from the Chinle Formation collected by the USBM contains a minor amount of silver. These anomalies apparently are isolated occurrences, as the other samples collected and analyzed do not indicate the presence of anomalous concentrations of metals, and the anomalies are probably related to the presence of the Chinle Formation within the study area. Small quantitites of gold have been reported to occur in the Chinle Formation (Lawson, 1913; Butler and others, 1920), and silver has been mined from the Chinle Formation in southwestern Utah (Proctor, 1953). On the basis of geologic and geochemical studies, the Fiddler Butte (East) Wilderness Study Area is considered to have a moderate mineral resource potential for small, isolated occurrences of precious (gold and silver) metals. A certainty level of B is assigned on the basis of geologic and geochemical data provided by this study. Because of the lack of any other geochemical anomalies, and the absence of any mineralized rock, the study area is considered to have low mineral resource potential for all other metals, with certainty level B.

\section{Geothermal Energy}

There is no evidence, such as heated waters or associated mineral deposits, to suggest the shallow occurrence of geothermal sources in the study area. The Fiddler Butte (East) Wilderness Study Area has a low resource potential for geothermal energy. A certainty level of $\mathrm{B}$ is assigned based on the lack of geologic evidence for geothermal sources in the study area. 

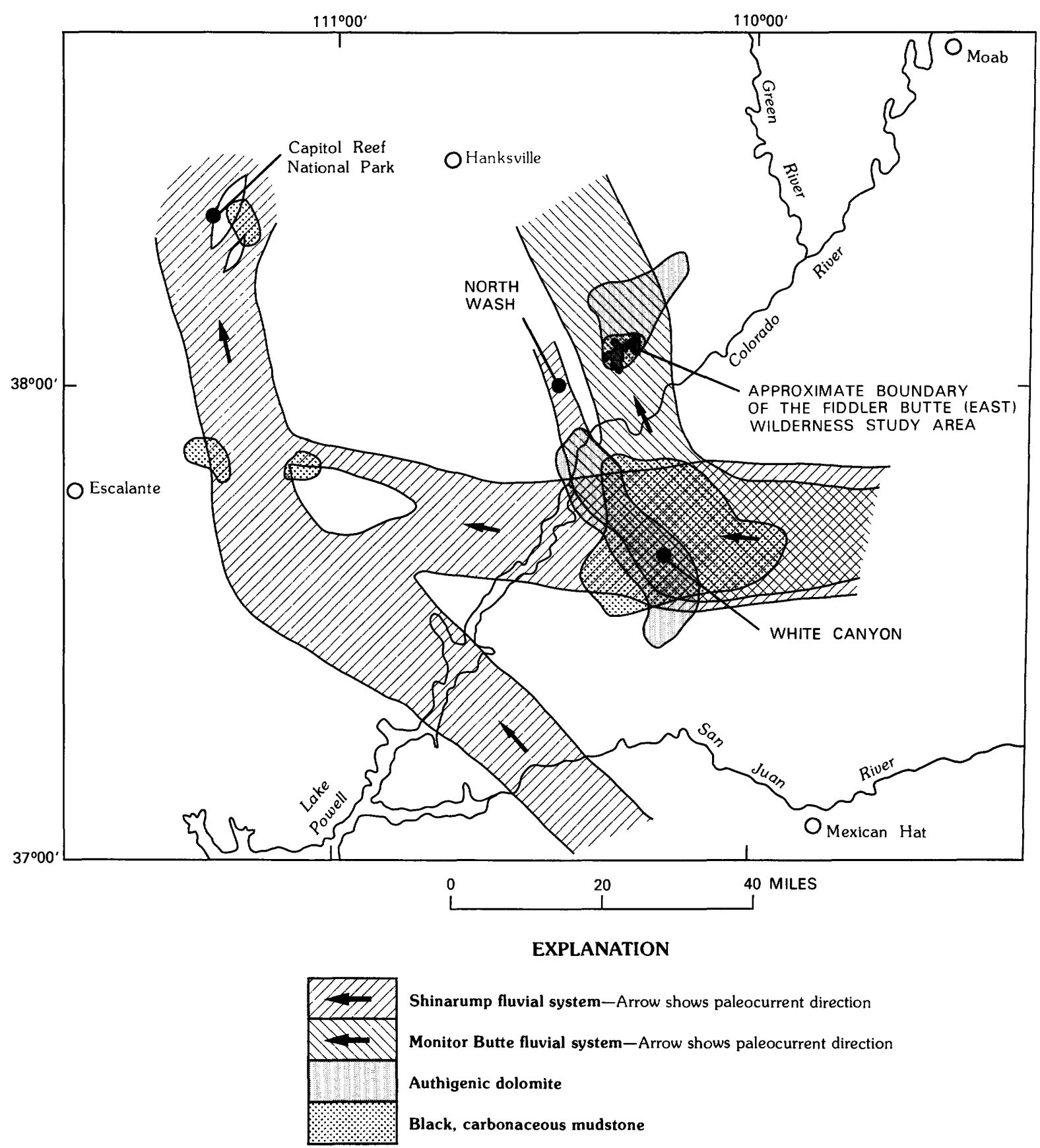

Shinarump fluvial system-Arrow shows paleocurrent direction

Monitor Butte fluvial system-Arrow shows paleocurrent direction

Authigenic dolomite

Black, carbonaceous mudstone

Figure 3. Map showing distribution of the fluvial systems of the Shinarump and Monitor Butte Members of the Chinle Formation, authigenic dolomite, and black carbonaceous mudstones used to evaluate the uranium potential in the Fiddler Butte (East) Wilderness Study Area and vicinity. (Modified from Dubiel and others, 1985.)

\section{REFERENCES CITED}

Baars, D.L., 1962, Permian System of the Colorado Plateau: American Association of Petroleum Geologists Bulletin, v. 46 , p. $149-218$.

1979, The Permian System, in Baars, D.L., ed., Permianland: Four Corners Geological Society, 9th Field Conference Guidebook, p. 1-6.
1987, Paleozoic rocks of Canyonlands country, in Campbell, J.A., ed., Geology of Cataract Canyon and vicinity: Four Corners Geological Society, 10th Field Conference Guidebook, p. 11-16.

Baars, D.L., and Seager, W.R., 1970, Stratigraphic control of petroleum in White Rim Sandstone (Permian) in and near Canyonlands National Park, Utah: American Association of Petroleum Geologists Bulletin, v. 54, p. 709-718. 
Baker, A.A., 1935, Geologic structure of southeastern Utah: American Association of Petroleum Geologists Bulletin, v. 19 , no. 10 , p. $1472-1507$.

1946, Geology of the Green River Desert-Cataract Canyon region, Emery, Wayne, and Garfield Counties, Utah: U.S. Geological Survey Bulletin 951, 122 p.

Ball, Douglas, Marchant, L.C., and Goldburg, Arnold, eds., 1982, Tar sands: Oklahoma City, Okla., Interstate Oil Compact Commission Monograph Series, 232 p.

Bates, R.L., 1969, Geology of the industrial rocks and minerals: New York, Dover Publications, Inc., 459 p.

Blakey, R.C., 1979, Lower Permian stratigraphy of the southern Colorado Plateau, in Baars, D.L., ed., Permianlands: Four Corners Geological Society, 9th Field Conference Guidebook, p. 115-129.

Blakey, R.C., and Gubitosa, Richard, 1983, Late Triassic paleogeography and depositional history of the Chinle Formation, southern Utah and northern Arizona, in Reynolds, M.W. and Dolly, E.D., eds., Mesozoic paleogeography of the west-central United States: The Rocky Mountain Section, Society of Economic Paleontologists and Mineralogists, Rocky Mountain Paleogeography Symposium 2, p. 57-76.

Briggs, J.P., 1982, Mineral investigation of the Fiddler Butte Wilderness Study Area, Garfield County, Utah: U.S. Bureau of Mines Open File Report MLA 132-82, 19 p.

Butler, B.S., Loughlin, G.F., and Heikes, V.C., 1920, The ore deposits of Utah: U.S. Geological Survey Professional Paper 111, $672 \mathrm{p}$.

Campbell, J.A., 1975, Oil-impregnated sandstone deposits of Utah: Mining Engineering, v. 27, p. 47-51.

Campbell, J.A., ed., 1987, Geology of Cataract Canyon and vicinity: Four Corners Geological Society, 10th Field Conference Guidebook, 200 p.

Campbell, J.A., and Ritzma, H.R., 1979, Geology and petroleum resources of the major oil-impregnated sandstone deposits of Utah: Utah Geological and Mineralogical Survey Special Studies 50, 24 p.

1982 , Geology and petroleum resources of major oilimpregnated sandstone deposits of Utah, in Ball, Douglas, Marchant, L.C., and Goldburg, Arnold, eds., Tar sands: Oklahoma City, Okla., Interstate Oil Compact Commission Monograph Series, p. 27-43.

Carr, D.D., and Rooney, L.F., 1983, Limestone and dolomite, in Lefond, S.J., ed., Industrial minerals and rocks: New York, American Institute of Mining, Metallurgical, and Petroleum Engineers, Inc., p. 833-868.

Centanni F.A., Ross, A.M., and DeSesa, M.A., 1956, Fluorometric determination of uranium: Analytical Chemistry, v. 28, p. 1651-1657.

Coope, B.M., and Harben, P.W., 1977, Silica sand, in Harben, P.W., ed., Raw materials for the glass industry: Metal Bulletin, Ltd., 131 p.

Crock, J.G., Briggs, P.H., Jackson, L.L., and Lichte, F.E., 1987, Analytical methods for the analysis of stream sediments and rock samples from wilderness study areas: U.S. Geological Survey Open-File report 87-84, 35 p.

Davis, L.L., and Tepordei, V.V., 1985, Sand and gravel, in Mineral facts and problems: U.S. Bureau of Mines Bulletin 675, p. 689-703.
Doelling, H.H., 1967, Uranium deposits of Garfield County, Utah: Utah Geological and Mineralogical Survey Special Studies 22, $113 \mathrm{p}$.

1975, Geology and mineral resources of Garfield County, Utah: Utah Geological and Mineralogical Survey Bulletin 107, 175 p.

Dubiel, R.F., 1982, Measured sections of the Shinarump, Monitor Butte, and Moss Back Members of the Chinle Formation (Upper Triassic) in the White Canyon and Red Canyon area, southeastern Utah: U.S. Geological Survey Open-File Report 82-729, 25 p.

1983a, Measured sections of the Shinarump, Monitor Butte, and Moss Back Members of the Chinle Formation (Upper Triassic) in the northern part of the White Canyon, Red Canyon, and Blue Notch Canyon area, southeastern Utah: U.S. Geological Survey Open-File Report 83-188, 30 p.

$1983 \mathrm{~b}$, Sedimentology of the lower part of the Upper Triassic Chinle Formation and its relationship to uranium deposits, White Canyon area, southeastern Utah: U.S. Geological Survey Open-File Report 83-459, $48 \mathrm{p}$.

1987a, Sedimentology and new fossil occurrences of the Upper Triassic Chinle Formation, southeastern Utah, in Campbell, J.A., ed., Geology of Cataract Canyon and vicinity: Four Corners Geological Society, 10th Field Conference Guidebook, p. 99-107.

1987b, Sedimentology of the Upper Triassic Chinle Formation, southestern Utah: Boulder, Colo., University of Colorado, Ph.D. dissertation, 132 p.

1987c, Sedimentology of the Upper Triassic Chinle Formation, southeastern Utah-Paleoclimatic implications, in Morales, Michael, and Elliott, D.K., eds., Triassic continental deposits of the American Southwest: Journal of the Arizona-Nevada Academy of Science, $v$. 22 , p. $35-45$.

Dubiel, R.F., Larson, M.J., Peterson, Fred, and Willson, W.R., 1985, Mineral resource potential map of the Dirty Devil, French Spring-Happy Canyon, and Horseshoe Canyon Wilderness Study Areas, Wayne and Garfield Counties, Utah: U.S. Geological Survey Miscellaneous Field Studies Map MF-1754-A, scale 1:50,000.

Gese, D.D., 1988, Mineral resources of part of the Fiddler Butte Wilderness Study Area (UT-050-241), Garfield County, Utah: U.S. Bureau of Mines Open File Report MLA 37-88, 16 p.

Goudarzi, G.H., compiler, 1984, Guide to preparation of mineral survey reports on public lands: U.S. Geological Survey Open-File Report 84-787, 42 p.

Grimes, D.J., and Marranzino, A.P., 1968, Direct-current arc and alternating-current spark emission spectrographic field methods for the semiquantitative analysis of geologic materials: U.S. Geological Survey Circular 591, $6 \mathrm{p}$.

Huntoon, J.E., and Chan, M.A., 1987, Marine origin of paleotopographic relief on eolian White Rim Sandstone (Permian), Elaterite basin, Utah: American Association of Petroleum Geologists Bulletin, v. 71, p. 1035-1045. 
Huntoon, P.W., Billingsley, G.H., Jr., and Breed, W.J., 1982, Geologic map of Canyonlands National Park and vicinity, Utah: Moab, Utah, Canyonlands Natural History Association, 2 sheets, scale 1:62,500.

Irwin, C.D., Clark, W.R., and Peabody, W.W., 1980, Petroleum geology of the Henry Mountains basin, in Picard, M.D., ed., Henry Mountains symposium: Utah Geological Association Publication 8, p. 353-366.

Johnson, H.S., 1959, Uranium resources of the Green River and Henry Mountains districts, Utah-A regional synthesis: U.S. Geological Survey Bulletin 1087-C, 104 p.

Larson, M.J., Bromfield, C.S., Dubiel, R.F., Orkild, P.P., Patterson, C.G., and Peterson, Fred, 1985, Geologic maps of the Fiddler Butte Wilderness Study Area and Fremont Gorge Study Area, Garfield and Wayne Counties, Utah: U.S. Geological Survey Miscellaneous Field Studies Map MF-1755-B, scale 1:50,000.

Larson, M.J., Dubiel, R.F., Peterson, Fred, Willson, W.R., and Briggs, J.P., 1985, Mineral resource potential of the Fiddler Butte Wilderness Study Area and the Fremont Gorge Study Area, Garfield and Wayne Counties, Utah: U.S. Geological Survey Miscellaneous Field Studies Map MF-1755-A, scale 1:50,000.

Lawson, A.C., 1913, Gold of the Shinarump at Paria: Economic Geology, v. 8, p. 434-448.

McKelvey, V.E., Mineral resource estimates and public policy: American Scientist, v. 60 , p. 32-40.

McKnight, E.T., 1940, Geology of the area between Green and Colorado Rivers, Grand and San Juan Counties, Utah: U.S. Geological Survey Bulletin 908, 147 p.

Molenaar, C.M., 1987, Mesozoic rocks of Canyonlands country, in Campbell, J.A., ed., Geology of Cataract Canyon and vicinity: Four Corners Geological Society, 10th Field Conference Guidebook, p. 19-24.

Molenaar, C.M., and Sandberg, C.A., 1983, Petroleum potential of wilderness lands in Utah: U.S. Geological Survey Circular 902-K, 13 p.

Molenaar, C.M., Sandberg, C.A., and Powers,. R.B., 1983, Petroleum potential of wilderness lands, Utah: U.S. Geological Survey Miscellaneous Investigations Series Map I-1545, scale 1:1,000,000.

Northrup, H.R., 1982, Origin of the tabular-type vanadiumuranium deposits in the Henry structural basin, Utah: Golden, Colo., Colorado School of Mines, Ph.D. thesis T-2614, 340 p.

Peterson, Fred, 1977, Uranium deposits related to depositional environments in the Morrison Formation (Upper Jurassic), Henry Mountains mineral belt of southern Utah, in Campbell, J.A., ed., Short papers of the U.S. Geological Survey uranium-thorium symposium, 1977: U.S. Geological Survey Circular 753, p. 45-47.

Poole, F.G. and Williams, G.A., 1972, Direction of sediment transport in the Triassic and associated formations of the Colorado Plateau, in Page, L.R., Stocking, H.E., and Smith, H.B., compilers, Contributions to the geology of uranium and thorium by the United States Geological Survey and Atomic Energy Commission for the United Nations international conference on peaceful uses of atomic energy, Geneva, Switzerland, 1955: U.S. Geological Survey Professional Paper 300, p. 227-231.

Powell, J.W., 1875, Exploration of the Colorado River of the west and its tributaries: Washington, D.C., U.S. Government Printing Office, 145 p.

Proctor, P.D., 1953, Geology of the Silver Reef (Harrisburg) mining district, Washington County, Utah: Utah Geological and Mineralogical Survey Bulletin 44, 169 p.

Ritzma, H.R., 1974, Oil-impregnated rock deposits of Utah: Utah Geological and Mineralogical Survey Map 33, 2 sheets, scale 1:1,000,000.

1979, Oil-impregnated rock deposits of Utah: Utah Geological and Mineralogical Survey Map 47, 2 sheets, scale $1: 1,000,000$.

Rose, A.W., Hawkes, H.E., and Webb, J.S., 1979, Geochemistry in mineral exploration, 2d ed.: San Francisco, Academic Press, p. 549-581.

Shoemaker, E.M., Miesch, A.T., Newman, W.L., and Riley, L.B., 1959, Elemental composition of the sandstone-type deposits, in Garrels, R.M., and Larsen, E.S., 3rd, comps., Geochemistry and mineralogy of the Colorado Plateau uranium ores: U.S. Geological Survey Professional Paper 320 , p. $25-54$

Steele, B.A., 1987, Depositional environments of the White Rim Sandstone Member of the Permian Cutler Formation, Canyonlands National Park, Utah: U.S. Geological Survey Bulletin 1592, 20 p.

Stewart, J.H., Poole, F.G., and Wilson, R.F., 1972a, Stratigraphy and origin of the Triassic Moenkopi Formation and related strata in the Colorado Plateau region with $a$ section on Sedimentary petrology, by R.A. Cadigan: U.S. Geological Survey Professional Paper 691, 195 p.

1972b, Stratigraphy and origin of the Upper Triassic Chinle Formation and related strata on the Colorado Plateau with a section on Sedimentary petrology, by R.A. Cadigan: U.S. Geological Survey Professional Paper 690, $336 \mathrm{p}$.

Stokes, W.L., 1980, Stratigraphic interpretations of the Triassic and Jurassic beds of the Henry Mountains area, in Picard, M.D. ed., Henry Mountains symposium: Utah Geological Association Publication 8, p. 113-122.

Thompson, C.E., Nakagawa, H.M., and Van Sickle, G.H., 1968, Rapid analysis for gold in geologic materials: U.S. Geological Survey Professional Paper 600-B, p. B130-B132.

U.S. Bureau of Mines and U.S. Geological Survey, 1980, Principles of a resource/reserve classification for minerals: U.S. Geological Survey Circular 831, 5 p.

Wood, R.E., and Ritzma, H.R., 1972, Analyses of oil extracted from oil-impregnated sandstone deposits of Utah: Utah Geological and Mineralogical Survey Special Studies 39, $19 \mathrm{p}$. 



\section{APPENDIX}




\section{DEFINITION OF LEVELS OF MINERAL RESOURCE POTENTIAL AND CERTAINTY OF ASSESSMENT}

\section{Definitions of Mineral Resource Potential}

LOW mineral resource potential is assigned to areas where geologic, geochemical, and geophysical characteristics define a geologic environment in which the existence of resources is unlikely. This broad category embraces areas with dispersed but insignificantly mineralized rock as well as areas with few or no indications of having been mineralized.

MODERATE mineral resource potential is assigned to areas where geologic, geochemical, and geophysical characteristics indicate a geologic environment favorable for resource occurrence, where interpretations of data indicate a reasonable likelihood of resource accumulation, and (or) where an application of mineral-deposit models indicates favorable ground for the specified type(s) of deposits.

HIGH mineral resource potential is assigned to areas where geologic, geochemical, and geophysical characteristics indicate a geologic environment favorable for resource occurrence, where interpretations of data indicate a high degree of likelihood for resource accumulation, where data support mineral-deposit models indicating presence of resources, and where evidence indicates that mineral concentration has taken place. Assignment of high resource potential to an area requires some positive knowledge that mineral-forming processes have been active in at least part of the area.

UNKNOWN mineral resource potential is assigned to areas where information is inadequate to assign low, moderate, or high levels of resource potential.

NO mineral resource potential is a category reserved for a specific type of resource in a well-defined area.

Levels of Certainty

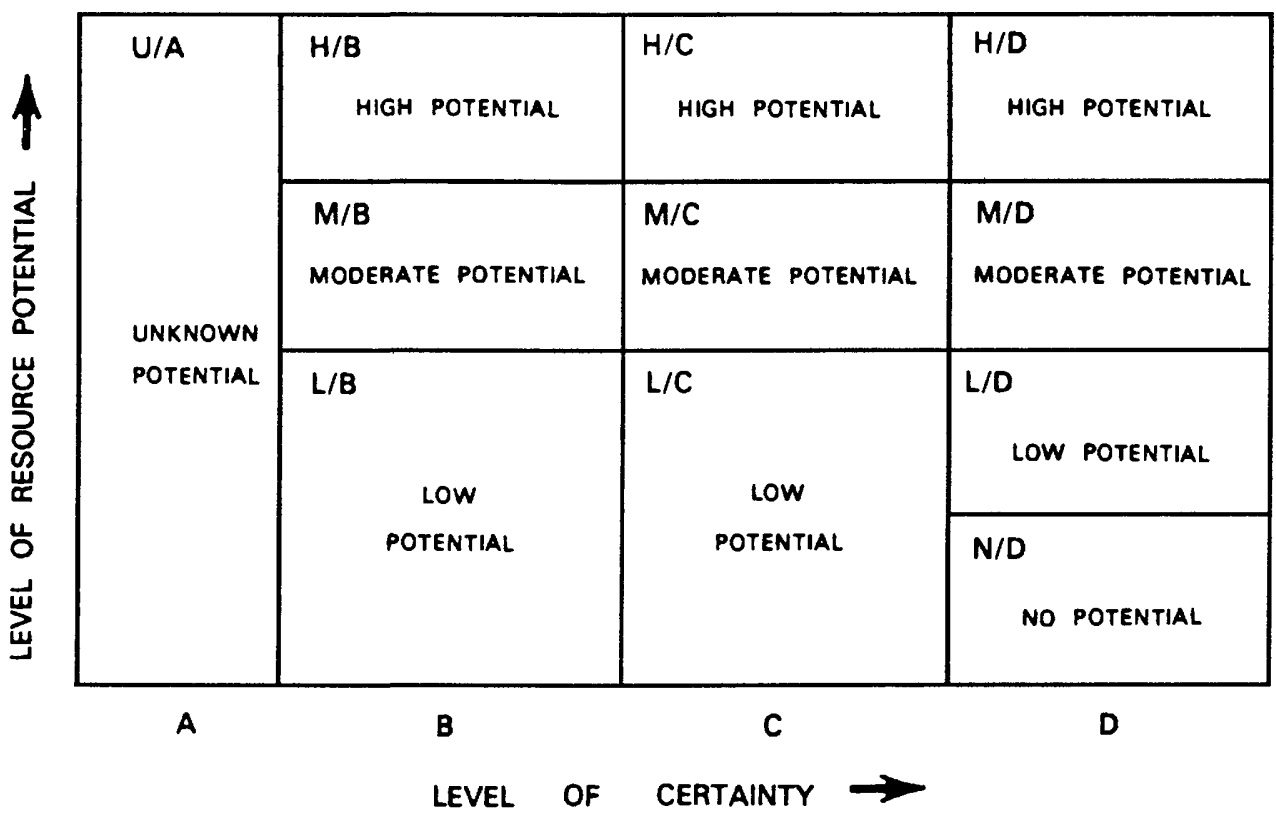

A. Available information is not adequate for determination of the level of mineral resource potential.

B. Available information suggests the level of mineral resource potential.

C. Available information gives a good indication of the level of mineral resource potential.

D. Available information clearly defines the level of mineral resource potential.

\section{Abstracted with minor modifications from:}

Taylor, R. B., and Steven, T. A., 1983, Definition of mineral resource potential: Economic Geology, v. 78, no. 6 , p. $1268-1270$.

Taylor, R. B., Stoneman, R. J., and Marsh, S. P., 1984, An assessment of the mineral resource potential of the San Isabel National Forest, south-central Colorado: U.S. Geological Survey Bulletin 1638, p. $40-42$.

Goudarzi, G. H., compiler, 1984, Guide to preparation of mineral survey reports on public lands: U.S. Geological Survey Open-File Report 84-0787, p. 7, 8. 


\section{RESOURCE/RESERVE CLASSIFICATION}

\begin{tabular}{|c|c|c|c|c|c|}
\hline & \multicolumn{3}{|c|}{ IDENTIFIED RESOURCES } & \multirow{2}{*}{\multicolumn{2}{|c|}{$\frac{\text { UNDISCOVERED RESOURCES }}{\text { Probability Range }}$}} \\
\hline & \multicolumn{2}{|c|}{ Demonstrated } & \multirow{2}{*}{ Inferred } & & \\
\hline & Measured & Indicated & & Hypothetical & Speculative \\
\hline ECONOMIC & Res & & Inferred Reserves & & \\
\hline $\begin{array}{l}\text { MARGINALLY } \\
\text { ECONOMIC }\end{array}$ & Margina & Reserves & $\begin{array}{c}\text { Inferred } \\
\text { Marginal Reserves }\end{array}$ & & \\
\hline $\begin{array}{c}\text { SUB- } \\
\text { ECONOMIC }\end{array}$ & $\begin{array}{r}\text { Demo } \\
\text { Subeconon }\end{array}$ & $\begin{array}{l}\text { trated } \\
\text { Resources }\end{array}$ & $\begin{array}{l}\text { Inferred } \\
\text { Subeconomic } \\
\text { Resources }\end{array}$ & & \\
\hline
\end{tabular}

Major elements of mineral resource classification, excluding reserve base and inferred reserve base. Modified from McKelvey, 1972, Mineral resource estimates and public policy: American Scientist, v.60, p.32-40, and U.S. Bureau of Minss and U.S. Geological Survey, 1980, Principles of a resource/reserve classification for minerals: U.S. Geological Survey Circular 831, p.5. 
GEOLOGIC TIME CHART

Terms and boundary ages used in this report

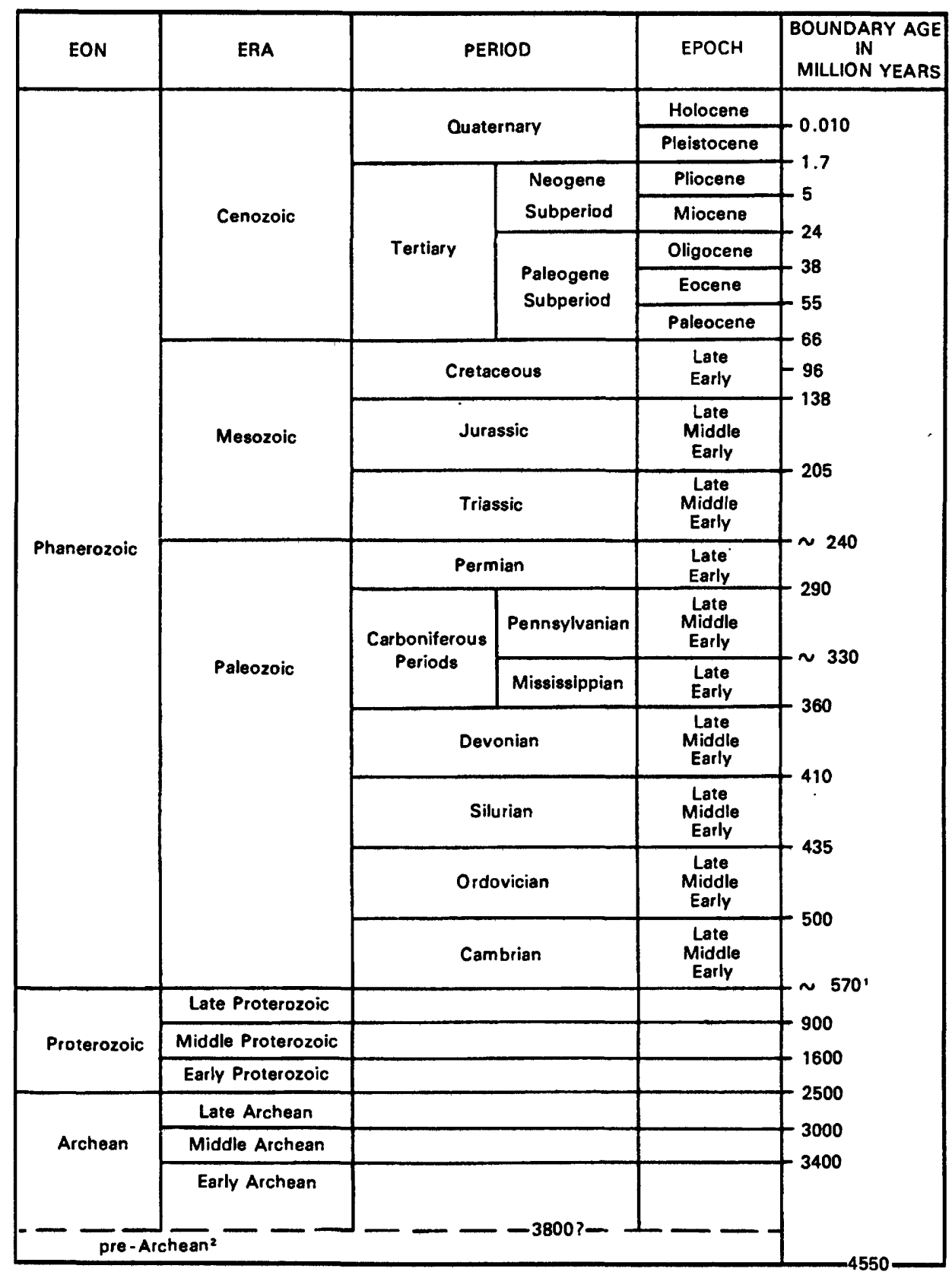

'Rocks older than $570 \mathrm{~m}$.y. also called Precambrian, a time term without specific rank.

2 Informal time term without specific rank. 